J. Clin. Chem. Clin. Biochem.

Vol. 27, 1989, pp. 175-179

(C) 1989 Walter de Gruyter \& Co.

Berlin $\cdot$ New York

\title{
Immunoassay by Particle Counting for Coagulation Testing: Application to the Determination of Antithrombin III, von Willebrand Factor Antigen (vWF:Ag) and Plasminogen
}

By L. Borque, C. Cambiaso

Unit of Experimental Medicine, International Institute for Cellular and Molecular Pathology, Bruxelles, Belgium

E. Lavenne

Hemostase et Thrombose, Cliniques Universitaires St-Luc, Bruxelles, Belgium

\section{P. Leautaud}

Institut Médico-Chirurgical d'Ixelles, Bruxelles, Belgium

J. C. Mareschal and D. Collet-Cassart

Unit of Experimental Medicine, International Institute for Cellular and Molecular Pathology, Bruxelles, Belgium

(Received July 4/October 31,1988 )

Summary: Based on immunoassay by particle counting, three methods for antithrombin III, von Willebrand factor and plasminogen were developed on an automated IMPACT ${ }^{\circledR}$ machine and on a semi-automated MULTIPACT ${ }^{\circledR}$ system. Precision of the techniques, measured at low, medium and high level of the calibration curve showed coefficients of variation varying from 4.3 to $13.8 \%$. Accuracy was evaluated by dilution recovery test and by correlation with rocket immunoelectrophoresis and chromogenic substrate techniques. The results show that the proposed methods correlate well with existing techniques and that immunoassay by particle counting is applicable to several coagulation tests.

\section{Introduction}

Immunoassay by particle counting is based on latex particle agglutination, where the extent of the reaction is measured by counting the remaining number of non-agglutinated particles in a particle counter designed for light scattering measurements. The particles coated with $F(a b)_{2}$ fragments of antibodies are agglutinable by the antigens to be measured: the number of remaining free particles, or monomers, is inversely proportional to the antigen concentration.

This technique, previously called Particle Counting Immunoassay, has been reviewed elsewhere (1). Applications were developed for large antigens such as $\alpha$-fetoprotein (2), ferritin (3), IgE (4), or for small molecules like digoxin (5), and also for antibodies (6, 7) and immune complexes (8).

We present here three convenient immunoassays for the determination of antithrombin III, von Willebrand factor antigen and plasminogen. The three assays have incubation times varying from 15 to 60 minutes and are performed either in an automatic mode on the IMPACT ${ }^{\circledR}$ machine (Acade Diagnostic Systems, Louvain-la-Neuve, Belgium) or in a semi-automatic mode using the modular new high throughput MULTIPACT ${ }^{\circledR}$ system (Acade Diagnostic Systems, Louvain-la-Neuve, Belgium). Both systems operate on the 
same principle and have the same incubation medium; they differ in reaction volumes, incubation time and in the handling of reagents and samples. The performances of these methods were compared with classical "rocket immunoelectrophoresis" and with chromogenic substrate techniques.

\section{Materials and Methods}

\section{Reagents and buffers}

Estapor $\mathrm{K} 1500.8 \mu \mathrm{m}$ latex particles were from Rhone-Poulenc (Courbevoie, France).

Bovine serum albumin, Fraction $V$ was from the Biochemical Corporation (Cleveland, USA) and human transferrin from Behringwerke AG (Marburg/Lahn, FRG).

Anti-vWF:Ag and anti-plasminogen antibodies were obtained from DAKO (Dakopatts, Sweden) as IgG solutions.

Anti-antithrombin III antiserum was purchased from Behringwerke AG Marburg/Lahn, FRG).

"Glycine-buffered saline" was $0.1 \mathrm{~mol} / 1$ glycine, $0.17 \mathrm{~mol} / 1 \mathrm{NaCl}$ and contained $40 \mathrm{mg}$ of sodium azide per litre; the $\mathrm{pH}$ was adjusted to 9.2 with $\mathrm{NaOH}$.

Glycine buffered saline/bovine serum albumin $1 \mathrm{~g} / \mathrm{l}$ and glycine buffered saline/bovine serum albumin $10 \mathrm{~g} / \mathrm{l}$ were glycine-buffered saline containing respectively $1 \mathrm{~g}$ and $10 \mathrm{~g}$ bovine serum albumin per litre.

Glycine buffered saline transferrin was glycine buffered saline containing $1 \mathrm{~g} / \mathrm{l}$ transferrin (Behringwerke, Marburg/Lahn, FRG).

Glycine buffered saline Tween was glycine-buffered saline containing $0.2 \mathrm{ml}$ of Tween ${ }^{\circledR} 20$ (Technicon Instruments, Corp., Tarrytown, USA) per litre.

\section{Isolation of IgG from antiserum}

IgG of the rabbit anti-antithrombin III were affinity-purified on a Protein A-Sepharose column (Pharmacia, Uppsala, Sweden). After adsorption in neutral conditions, the IgG were eluted with $0.1 \mathrm{~mol} / 1$ glycine- $\mathrm{HCl}$ pH 3 buffer containing 0.5 $\mathrm{mol} / 1 \mathrm{NaCl}$, precipitated in $50 \%$ saturated ammonium sulphate, redissolved and dialysed against saline.

\section{Preparation of $\mathrm{F}(\mathrm{ab})_{2}{ }_{2}$ fragments of $\mathrm{IgG}$}

$\mathrm{F}(\mathrm{ab})_{2}{ }_{2}$ fragments of the rabbit IgG, anti-antithrombin III, antivWF:Ag and anti-plasminogen were prepared as described in l.c. (2).

\section{Coupling of $F(a b)_{2}$ fragments to latex particles}

Carboxylated latex particles were covalently coated with the different $F(a b)_{2}^{\prime}$ fragments as described previously (9). The protein/latex weight ratios were respectively $1 / 50$ for the antithrombin III assay, 1/100 for the vWF:Ag and the plasminogen assays.

The coated latexes were suspended at concentrations of $0.5 \mathrm{~g} / 1$ in glycine buffered saline containing $1 \mathrm{~g} / \mathrm{l}$ bovine serum albumin for the vWF:Ag and plasminogen assay, and in glycine buffered saline containing $1 \mathrm{~g} / 1$ of transferrin for the antithrombin III assay. For long term storage these suspensions were kept at $-20^{\circ} \mathrm{C}$ or were freeze-dried.

\section{Automated procecures}

The automated assays were performed on the IMPACT ${ }^{\otimes}$ instrument. This apparatus consists of a thermostated vortexing tray for samples and reaction tubes, and four automatic pipetting-diluting stations. This module is connected with the optical bench of the particle counter via a continuous flow manifold operated by a peristaltic pump. All operation controls and data treatments are performed with a desk-top computer; counting results are expressed as peak heights.

The IMPACT ${ }^{\circledR}$ was used according to the specifications of the manufacturer.

Table 1 shows the assay characteristics of the three automated assays. After an off-line dilution step, samples are further diluted in the machine; $30 \mu \mathrm{l}$ of diluted sample are then mixed with $30 \mu \mathrm{l}$ of activated latex particles in a reaction tube, followed by incubation for 30 minutes at $37^{\circ} \mathrm{C}$. Reactions are stopped by dilution of the reaction mixture. An aliquot of latex suspen= sions is then further diluted in the manifold and passes through the flow cell for optical measurement of the remaining monomers of latex particles. The throughput is 60 samples/hour. Single determinations were performed.

\section{Semi-automated assay procedures}

The semi-automated assays were performed using the MULTIPACT ${ }^{\otimes}$ agitating and counting modules. After a predilution step, the samples were dispensed into $1 \mathrm{ml}$ polystyrene tubes on a 48-position rack and mixed with latex reagents in the thermostated vortexing agitator.

The reactions were stopped by diluting the particles with glycine buffered saline containing $0.1 \mathrm{~mol} / 1$ EDTA and the reaction tubes were placed in the counting module. The throughput is 180 samples/hour. Single determinations were performed.

The system was used according to the specifications of the manufacturer.

Table 2 summarizes the assay characteristics of the semi-automated methods.

\section{Comparison methods}

Chromogenic substrate kits, Coatest ${ }^{\oplus}$ S-2251 for plasminogen and S-2238 for antithrombin III, were from Kabi Vitrum AB (Mölndal, Sweden). Rocket immunoelectrophoresis was performed as described by Laurell (10).

\section{Standards and control}

A pool of fresh plasma from 12 healthy donnors was calibrated with the Reference Plasma $100 \%$ obtained from Immuno AG (Vienna, Austria). The antigen concentrations were $1.5 \mathrm{mg} / \mathrm{l}$ for antithrombin III, $7 \mathrm{mg} / \mathrm{l}$ for $\mathrm{vWF}: \mathrm{Ag}$ and $0.2 \mathrm{mg} / \mathrm{l}$ for plasminogen. For convenience and in conformity with usual practice, standards were expressed in \% (11). The pool of plasma was diluted to prepare $400 \%, 200 \%, 100 \%, 50 \%, 25 \%$, $12.5 \%$ and $6.25 \%$ standards (tab. 3 ).

For antithrombin III, the pool of plasma was diluted in glycine buffered saline/Tween. For vWF:Ag and plasminogen, the pool of plasma was diluted in glycine buffered saline containing $1 \mathrm{~g} / \mathrm{l}$ bovine serum albumin, while for plasminogen on MULTIPACT ${ }^{\circ}$ the plasma had to be diluted in glycerine buffered saline containing $10 \mathrm{~g} / \mathrm{l}$ bovine serum albumin. 
Tab. 1. Characteristics of the three assays on IMPACT

\begin{tabular}{|c|c|c|c|c|c|c|}
\hline & $\begin{array}{l}\text { Off-line } \\
\text { dilution } \\
\text { of plasma }\end{array}$ & $\begin{array}{l}\text { Automated } \\
\text { dilution } \\
\text { of plasma }\end{array}$ & $\begin{array}{l}\text { Sample } \\
\text { volume } \\
(\mu 1)\end{array}$ & $\begin{array}{l}\text { Latex } \\
\text { reagent } \\
\text { volume } \\
(\mu l)\end{array}$ & $\begin{array}{l}\text { Incubation } \\
\text { time } \\
(\mathrm{min}) \\
37^{\circ} \mathrm{C}\end{array}$ & $\begin{array}{l}\text { Stopping } \\
\text { dilution } \\
(\mu l)\end{array}$ \\
\hline $\begin{array}{l}\text { Antithrombin III } \\
\text { vWF:Ag } \\
\text { Plasminogen }\end{array}$ & $\begin{array}{l}1: 200^{a} \\
1: 4^{b} \\
1: 200^{b}\end{array}$ & $\begin{array}{l}1: 45^{a} \\
1: 37^{b} \\
1: 32^{b}\end{array}$ & $\begin{array}{l}30 \\
30 \\
30\end{array}$ & $\begin{array}{l}30 \\
30 \\
30\end{array}$ & $\begin{array}{l}30 \\
30 \\
30\end{array}$ & $\begin{array}{l}1000^{b} \\
1000^{b} \\
1000^{b}\end{array}$ \\
\hline
\end{tabular}

a with glycine buffered saline/Tween

b with glycine buffered saline containing $1 \mathrm{~g} / \mathrm{l}$ bovine serum albumin

Tab. 2. Characteristics of the three assays on MULTIPACT

\begin{tabular}{lllll}
$\begin{array}{l}\text { Plasma } \\
\text { dilution }\end{array}$ & $\begin{array}{l}\text { Sample } \\
\text { volume } \\
(\mu \mathrm{l})\end{array}$ & $\begin{array}{l}\text { Latex } \\
\text { reagent } \\
\text { volume } \\
(\mu \mathrm{l})\end{array}$ & $\begin{array}{l}\text { Incubation } \\
\text { time } \\
(\min ) \\
37^{\circ} \mathrm{C}\end{array}$ & $\begin{array}{l}\text { Stopping } \\
\text { dilution } \\
(\mu \mathrm{l})\end{array}$ \\
\hline $1: 5000^{\mathrm{a}}$ & 25 & 25 & 60 & 750 \\
$1: 400^{\mathrm{b}}$ & 25 & 25 & 30 & 750 \\
$1: 16000^{\mathrm{c}}$ & 25 & 25 & 15 & 750 \\
\hline
\end{tabular}

Antithrombin III

vWF:Ag

Plasminogen

$1: 16000^{\circ}$

a with glycine buffered saline/Tween

b with glycine buffered saline containing $1 \mathrm{~g} / 1$ bovine serum albumin

c with glycine buffered saline containing $10 \mathrm{~g} / \mathrm{l}$ bovine serum albumin

Tab. 3. Preparation of standards from a pool of normal plasma

\begin{tabular}{|c|c|c|c|c|c|c|}
\hline Standard values & \multicolumn{3}{|l|}{ IMPACT ${ }^{\circledR}$} & \multicolumn{3}{|l|}{ MULTIPACT } \\
\hline $200 \%$ & $1: 100$ & $1: 2$ & $1: 100$ & $1: 2500$ & $1: 200$ & $1: 8000$ \\
\hline $100 \%$ & $1: 200$ & $1: 4$ & $1: 200$ & $1: 5000$ & $1: 400$ & $1: 16000$ \\
\hline $50 \%$ & $1: 400$ & $1: 8$ & $1: 400$ & $1: 10000$ & $1: 800$ & $1: 32000$ \\
\hline $6.25 \%$ & $1: 32000$ & $1: 64$ & $1: 3200$ & $1: 80000$ & $1: 6400$ & $1: 256000$ \\
\hline
\end{tabular}

\section{Results}

\section{Calibration}

Calibration curves were constructed by plotting the peak heights against the log of dilutions of the standard plasma, expressed as percentages of the standard plasma.

In each case, a sigmoïdal curve was obtained. Both IMPACT ${ }^{\circledR}$ and MULTIPACT ${ }^{\circledR}$ showed similar calibration curves. The calibration curves obtained on the IMPACT instrument are shown below (fig. 1).

\section{Linearities}

In order to assess the accuracy of the assays, we performed the dilution recovery test on each assay.
Five plasma were serially diluted in the appropriate dilution buffer, assayed in the MULTIPACT ${ }^{(3)}$ system, and the values of the diluted samples calculated.

Results for the three assays are reported on table 4 . The first dilutions, reported as $1: 1$ in table 4 , are related to plasma dilution from table 1 .

\section{Precision of the methods}

Intra-assay reproducibilities of the three methods were evaluated for three different levels of the standard curve on the MULTIPACT ${ }^{\circledR}$ system (tab. 5). Day to day variability as assessed by the IMPACT ${ }^{\text {(0) }}$ system with the Reference Plasma 100\% (Immuno AG), during ten days, gave $5.8 \%$ for antithrombin III, $5.3 \%$ for $\mathrm{vWF}: \mathrm{Ag}$ and $4.7 \%$ for plasminogen. 
Tab. 4. Dilution recovery tests performed on MULTIPACT

\begin{tabular}{lrrrrrl}
\hline & \multicolumn{5}{c}{ Plasma dilution } \\
\cline { 3 - 7 } & & $1: 1$ & $1: 2$ & $1: 4$ & $1: 8$ & $1: 16$ \\
\hline Anti- & Plasma & & & & & \\
thrombin & no. 1 & 115 & 57 & 27 & 16 & nd $^{\text {a }}$ \\
III & no. 2 & 148 & 68 & 28 & 16.5 & nd \\
& no. 3 & 104 & 49 & 28 & 14 & nd \\
& no. 4 & 137 & 71 & 31 & 16 & nd \\
& no. 5 & 78 & 34 & 20 & 11 & nd \\
vWF:Ag & Plasma & & & & & \\
& no. 1 & 211 & 121 & 53 & nd & nd \\
& no. 2 & 330 & 166 & 83 & 41 & 23 \\
& no. 3 & 315 & 160 & 74 & 42 & 18 \\
Plasmin- & no. 4 & 399 & 212 & 93 & 51 & 28 \\
ogen & Plasma & & & & & \\
& no. 1 & 142 & 76 & 37 & 20 & 10 \\
& no. 2 & 68 & 30 & 14 & 7 & - \\
& no. 3 & 94 & 41 & 22 & 7 & - \\
& no. 4 & 146 & 64 & 31 & 15 & - \\
\hline
\end{tabular}

a not determined.

Values are expressed as $\%$ of pool of normal plasma.

Tab. 5. Intra-assay precisions of the methods

\begin{tabular}{lrrr}
\hline & & Mean + SD & CV \% \\
\hline Antithrombin & Plasma & & \\
III $^{\mathrm{a}}$ & no. 1 & $19.2 \pm 1.2$ & 6.4 \\
& no. 2 & $88.7 \pm 5.4$ & 6.1 \\
& no. 3 & $134.5 \pm 10.7$ & 8.0 \\
vWV:Ag $^{b}$ & Plasma & & \\
& no. 1 & $23.3 \pm 3.2$ & 13.8 \\
& no. 2 & $102.0 \pm 4.3$ & 4.3 \\
& no. 3 & $158.4 \pm 6.9$ & 4.4 \\
Plasminogen & & & \\
& Plasma & & 7.7 \\
& no. 1 & $15.0 \pm 1.2$ & 5.2 \\
& no. 2 & $111.8 \pm 5.8$ & 6.4 \\
& no. 3 & $241.3 \pm 15.4$ & \\
\hline
\end{tabular}

a 10 determinations

b 12 determinations

Values are expressed as \% of pool of normal plasma.

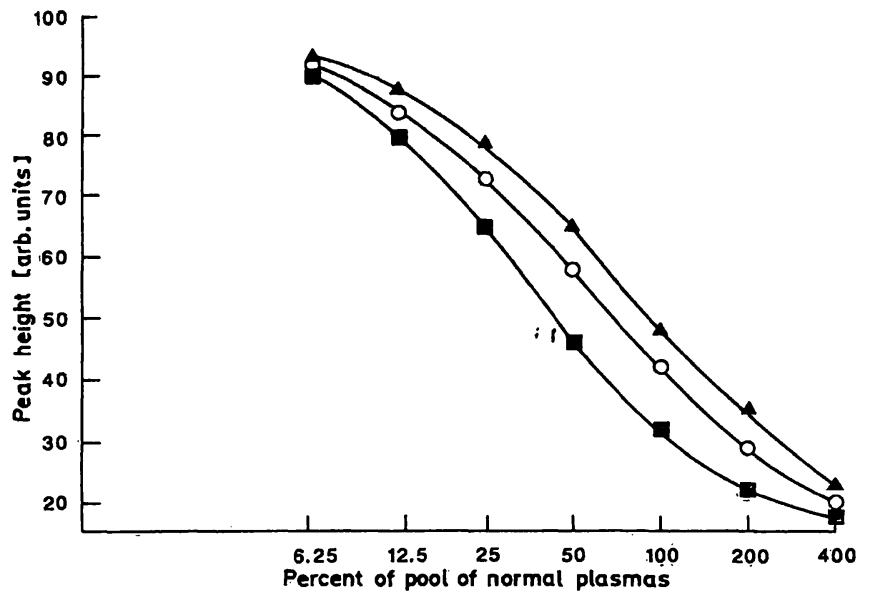

Fig. 1. Typical calibration curves of the three assays performed on the IMPACT instrument. Single measurements were performed.

- Plasminogen

O vWF:Ag

A Antithrombin III

\section{Correlation studies}

Immunoassays using the IMPACT ${ }^{\circledR}$ system were compared with rocket immunoelectrophoresis (all three methods), and with chromogenic substrate techniques for antithrombin III and plasminogen (tab. 6). Rocket immunoelectrophoresis and chromogenic substrate methods were performed with citrated plasma, which was centrifuged and immediately frozen at $-20^{\circ} \mathrm{C}$. No differences were observed between assays made on fresh and frozen samples.

IMPACT ${ }^{\circledR}$ measurements were performed on samples stored at $-20^{\circ} \mathrm{C}$ for one to two weeks.

Tab. 6. Correlations between immunoassays by particle counting (y) and other methods $(x)$

\begin{tabular}{|c|c|c|c|c|}
\hline Analysis & $\begin{array}{l}\text { Number } \\
\text { of sample }\end{array}$ & Compared method & $\begin{array}{l}\text { Linear regression/ } \\
\text { correlation coefficient }\end{array}$ & $\begin{array}{l}\text { Measuring range } \\
\text { (\% of pool of } \\
\text { normal plașma) }\end{array}$ \\
\hline \multirow[t]{2}{*}{ Antithrombin III } & 163 & $\begin{array}{l}\text { Chromogenic substrate } \\
\text { S-2238 }\end{array}$ & $\begin{array}{l}y=6.813+0.828 x \\
r=0.947\end{array}$ & $15=40$ \\
\hline & 110 & $\begin{array}{l}\text { Rocket } \\
\text { immunoelectrophoresis }\end{array}$ & $\begin{array}{l}y=5.920+0.874 x \\
r=0.893\end{array}$ & $50-130$ \\
\hline vWF:Ag & 104 & $\begin{array}{l}\text { Rocket } \\
\text { immunoelectrophoresis }\end{array}$ & $\begin{array}{l}y=13.071+1.463 x \\
r=0.938\end{array}$ & $40-400$ \\
\hline \multirow[t]{2}{*}{ Plasminogen } & 130 & $\begin{array}{l}\text { Chromogenic substrate } \\
\text { S-2251 }\end{array}$ & $\begin{array}{l}y=3.487+0.945 x \\
r=0.946\end{array}$ & $20-140$ \\
\hline & 95 & $\begin{array}{l}\text { Rocket } \\
\text { immunoelectrophoresis }\end{array}$ & $\begin{array}{l}y=2.5+0.819 x \\
r=0.855\end{array}$ & $30-160$ \\
\hline
\end{tabular}




\section{Discussion}

The techniques described in this paper offer several advantages. First of all, based on latex agglutination combined with optical measurement, these methods are non-radioisotopic and homogeneous; no separation steps are required during the assays. The homogeneous system allows automation of the reaction. With the requirement of a predilution step, the methods are completely automated with the IMPACT system while the MULTIPACT presents a convenient semi-automated system: after hand pipetting of samples and reagents, the rack of tubes is manually placed in the agitator module, then transferred to the optical reader for automatic particle counting. The IMPACT system is well adapted for assaying the same antigen in long series of samples while MULTIPACT ${ }^{\circledR}$ is suitable for measuring different antigens in smaller numbers of samples. Latex reagents were usable in both system and sample dilutions had to be adapted for each system.

We made only one reagent modification, i.e. the dilution buffer for plasminogen assay in MULTIPACT ${ }^{\circledR}$ system: instead of glycine buffered saline containing $1 \mathrm{~g} / \mathrm{l}$ bovine serum albumin, we used glycine buffered saline containing $10 \mathrm{~g} / 1$ bovine serum albumin. This was found to be necessary, owing to the very high dilutions performed for this assay on the MULTI$\mathrm{PACT}^{\circledR}$ system. The presence of a fairly high bovine serum albumin concentration prevented denaturation or adsorption of plasminogen onto the plastic tubes.
High sample dilution is necessary because of the low threshold of sensitivity (below $\mu \mathrm{g} / \mathrm{l}$ ) of the technique; although this feature may appear to be a drawback, it can be overcome by using an automatic diluting device.

Comparisons of the methods with well established methods showed good correlations in all cases. Correlation coefficients below 0.9 were obtained with rocket immunoelectrophoresis for the antithrombin III and plasminogen assays, but this method is known to display a poor precision. This observation is confirmed by the excellent correlations with the respective chromogenic substrate assays. Dilution recovery tests did not reveal any tendency to overestimation or underestimation resulting from the plasma predilution. The good recovery results, together with the acceptable precision, lead us to believe that immunoassay by particle counting has a place in coagulation testing. In the laboratory of one of us ( $E$. Lavenne), these tests have been routinely performed for nearly two years and more than 5000 tests have been performed without problems so far.

\section{Acknowledgement}

This work was supported by "Institut pour l'Encouragement de la Recherche Scientifique dans l'Industrie et l'Agriculture". The authors wish to thank the excellent technical assistance of Mrs Francine Wellekens and of Mrs Suzanne Min.

\section{References}

1. Masson, P. L., Cambiaso, C. L., Collet-Cassart, D., Magnusson, C. G. M., Richards, C. B. \& Sindic, C. J. M. (1981) Methods in Enzymology 74, 106-139.

2. Collet-Cassart, D., Magnusson, C. G. M., Ratcliffe, J. G., Cambiaso, C. L. \& Masson, P. L. (1981) Clin. Chem. 27, 64-67.

3. Limet, J. N., Collet-Cassart, D., Magnusson, C. G. M., Sauvage, P., Cambiaso, C. L. \& Masson, P. L. (1982) J. Clin. Chem. Clin. Biochem. 20, 141-146.

4. Magnusson, C. G. M., Collet-Cassart, D., Merrett, T. G. \& Masson, P. L. (1981) Clin. Allergy 11, 453-461.

5. Collet-Cassart, D., Magnusson, C. G. M., Cambiaso, C. L., Lesne, M. \& Masson, P. L. (1981) Clin. Chem. 27, 1205-1209.

6. Sindic, C. J. M., Chalon, M. P., Cambiaso, C. L., Laterre, E. C. \& Masson, P. L. (1981) Mol. Immunol. 18, 293299.

7. Magnusson, C. G. M., Djurup, R., Weeke, B. \& Masson, P. L. (1983) İntern. Arch. Allergy Appl. Immunol. 71, 144150.

8. Cambiaso, C. L., Riccomi, H., Sindic, C. \& Masson, P. L. (1978) J. Immunol. Methods 23, 29-50.

9. Collet-Cassart, D., Mareschal, J. C., Sindic, C. J. M., Tomasi, J. P. \& Masson, P. L. (1983) Clin. Chem. 29, 1127 1131.

10. Laurell, C. B. (1965) Ann. Biochem. 10, 358-361.

11. Stuart, M. J. (1987) "Hemostasis and Thrombosis", p. 942, G. B. Lippincott Company, Philadelphia.

Daniel Collet-Cassart

Unit of Experimental Medicine

International Institute of Cellular

and Molecular Pathology

Avenue Hippocrate, 75

B-1200 Brussels 
